\title{
Reformasi Birokrasi dalam Layanan Kesehatan: 112 Program Pusat Panggilan di Kota Pare-Pare
}

\author{
Srifatmawati Ahmda1), Muhammad Azizi'2), Yusriadi Yusriadi ${ }^{3) *}$, Akmal Umar'), \\ Abdul Sahid5) \\ 12) Program Studi, Public Administration Program, Universitas Tomakaka, indonesia \\ 3)*Public Administration Program. Sekolah Tinggi Ilmu Administrasi Puangrimaggalatung, \\ Indonesia \\ 2)Management Program, Sekolah Tinggi Ilmu Manajemen Indonesia \\ 3)Economic Program, STIE Amkop Makassar, Indonesia \\ 4)Public Administration Program, STIA Yappi Makassar, Indonesia
}

Diterima Februari, 2020; Disetujui April, 2020; Dipublikasikan Juni , 2020

\section{Abstrak}

Reformasi birokrasi adalah upaya untuk memperbarui sistem pemerintahan. Salah satu bentuk reformasi birokrasi adalah layanan kesehatan sebagai upaya menjaga dan meningkatkan kesehatan. Jenis penelitian yang digunakan adalah kualitatif, lokasi penelitian di Kota Pare-pare, informan dalam penelitian ini adalah delapan orang, yaitu empat pengguna layanan dan empat penyedia layanan, dengan observasi, wawancara, dan dokumentasi. Hasil dari program Call Center 112 di Kota Pare-pare menunjukkan bahwa implementasi program telah diimplementasikan dengan baik, inovasi dalam proses menyediakan layanan kesehatan terintegrasi kepada masyarakat menawarkan cara layanan baru, akses mudah ke layanan dengan menelepon langsung ke nomor 112 dengan layanan 24 jam selama tujuh hari. Konsep dalam program ini telah menyentuh masyarakat Kota Pare-pare dengan layanan kesehatan berkelanjutan dan mudah diakses oleh semua lapisan masyarakat.

Kata Kunci: Reformasi Birokrasi, Layanan Kesehatan, Indonesia, Inovasi Layanan

\section{Abstract}

Bureaucratic reform is an effort to renew the system of governance. One form of bureaucratic reform is health services as an effort to maintain and improve health. The type of research used was qualitative, the research location in Parepare City, informants in the study were eight people, namely four service users and four service providers, data explaining techniques with observation, interviews, and documentation. The results of the 112 Call Center program in Pare-pare City show that the implementation of the application has well implemented, innovation in the process of providing integrated health services to the community offers new ways of service, easy access to services by calling directly to number 112 with 24-hour service for seven days. The concept in this program has touched the people of Pare-pare City with continuous health services and is easily accessible to all levels of society.

Keywords: Bureaucratic Reform, Health Services, Indonesia, Service Innovation

How to Cite: Ahmda, S., dkk. (2020). Reformasi Birokrasi dalam Layanan Kesehatan: 112 Program Pusat Panggilan di Kota Pare-Pare. PUBLIKAUMA: Jurnal Ilmu Administrasi Publik UMA, 8 (1): 18-23

*Corresponding author:

E-mail: yusriadi.yusriadi@uqconnect.edu.au
ISSN 2549-9165 (Print)

ISSN 2580-2011 (Online 


\section{PENDAHULUAN}

In the era of industrial revolution 4.0, all parties required to provide the best to be number one and become the choice of society, including the organization. Government organizations are often known to be slow, convoluted in services required to move faster, and be appropriate in providing services to provide optimal service. Government organizations faced with the reality of having to know all the needs of the community so that they need to reform in response to those desires, reforms that demand innovation.

Health services are essential for every citizen. In the 1945 Constitution in Article 28 letter $(\mathrm{h})$, it is explained about health and Law Number 23 of 2010 that every individual, family, the community has the right to receive protection and health services. The state is responsible for fulfilling the needs of the right to the healthy life of every citizen. If the health of a region is low, it will have an impact on a low level of productivity; it will lead to poverty and a low level of community welfare. Therefore the regional government should improve service and innovation in improving services to public health. Health is one measure of people's protection.

All regional heads make efforts to improve the health status of their citizens. Including the mayor of Pare-pare, South Sulawesi, by presenting the emergency call center 112 service systems, as a city whose position is the gateway to the port of the archipelago, with a population reaching 140,423 inhabitants (BPS, 2016). Pare-pare City has an area of $99.33 \mathrm{~km}^{2}$ with four subdistricts and 22 sub-districts. The Pare-pare community burdened when experiencing pain. Before the free integrated health service program launched in October 2014, Pare-pare residents had to work hard to reach the health service center in the city. An integrated free health program (112 Call Center) was then born for free health services for Pare-pare residents in urban areas (Nawir, 2018).

Call Center 112 is an integrated health service for individuals and families; this service brings health services closer to the community because medical staff comes to the community at home. At present, there are several units of four-wheeled operational vehicles called Call Center 112, which have put on standby 24 hours (Pos, 2015).
Previous research on health services by Zindar Tamimi (2015) on public service management for emergency service teams is a form of reform from Bantaeng district with the theme of bringing services closer to the community. The results of his research revealed that one of the contributing factors to the success of the Bantaeng District Emergency Service Team was the mix management between government management, company management, and the balance between systems and culture is the key to the success of the Emergency Service Team (Tamimi, 2015).

The Call Center 112 program was recognized by Taufan Pawe as the original program and carried out by the Pare-pare City Government. The application was considered successful in its implementation so that it used as a reference for other local governments, integrated health service innovation (Call Center 112). According to Muhammad Yamin (Head of the Pare-pare Health Office), to provide convenience to residents. Establish cooperation with three cellular providers, allowing residents experiencing emergency conditions to contact Call Center 112 through their mobile phones; the three providers referred to are Simpati, Halo, and XL ( bappeda.Pare-pare.go.id). Reinforced by the many media that included the Call Center 112 program as an innovation, thanks to this service, the Municipal Government of Parepare entered the top 99 public service innovations in 2018 (Tahir, 2018).

Bureaucratic reform, according to Lee and Samonte (Nasucha, 2004). Innovation intentionally made to make the administrative system an agent of more effective social change and an instrument to guarantee political equality, social conditions, and economic growth. Thus the public sector can be a sector that can accommodate and respond quickly to any changes that occur (Suwarno \& Ikhsan, 2006).

Based on this, it is interesting to study the application of the 112 Call Center program in improving the quality of health services in the city of Pare-pare as an innovation by fulfilling specific criteria and analyzing. The concept of change in public services during the implementation of the program so that it can be a lesson for other local governments. 


\section{RESEARCH METHOD}

Research location in the city of Parepare, the selection based on the assumption that the 112 Call Center program will probably have an impact on the quality of public services, this study uses a qualitative approach with in-depth interview data collection on eight service users. Data collection techniques by interviewing and studying documents relating to health services, activities in data analysis include data reduction, data presentation, and drawing conclusions and verification.

\section{RESULTS AND DISCUSSION}

In this study, to measure the implementation of public service innovations seen from three indicators, namely the concept of change, and innovation typology.

\section{Concept Innovation}

One form of innovation by the Pare-pare City government is known as the 112 Call Center. The Pare-pare City health office is in charge of general management based on Mayor Pare-pare Regulation Number 22 of 2014 concerning 112 Call Center Health Service Guidelines in the Health Office.

The types of Call Center 112 services include emergency services, delivery services, and ambulance services. Emergency services give to people who are suddenly ill and must be dealt with immediately so that if 112 Call Center officers can handle them, the patient does not need to refer to the Public Health Center or Hospital. However, if further treatment is necessary, the 112 Call Center staff must bring the patient to the Community Health Center or Hospital. Childbirth services are services to pregnant women who will give birth, provided that 112 Call Center officers can handle them, so the patient does not need to go to the Hospital. If more treatment is required, the 112 Call Center officers must immediately bring the patient to the Hospital. Ambulance services are transportation services provided to people who need rapid health care from their homes to facilitate health services in Pare-pare City. Ambulance services equipped with drivers and operators who are always in the 112 Call Center service units.

\section{Innovation Typology}

According to Law Number 25 of 2009 that public services are activities to fulfill service needs following the laws and regulations for every citizen and resident for goods, services, administrative services provided by public service providers. Based on the results of the study, the 112 Call Center service innovations are a service process innovation, providing new ways of service; there were organizational changes, procedures, and policies when this service implemented. The 112 Call Center service is a retribution-free health service with a mobile system to make it easier for residents of Parepare City to get health services.

The 112 Call Center aims to bring access to health services closer to the community, reduce the workload of hospitals by not carrying out referral activities for patients in the hospital or the community. Hence, hospitals focus on implementing preventive health programs. The 112 Call Center has standard operating procedures to reach locations in the Pare-pare City area and has basic emergency service standards. Call Center 112 partners with community health centers and hospitals and health offices to support their implementation. All go through wellplanned paths, The Innovation Call Center 112 runs through a partnership mechanism.

Interview with several informants that the Innovation Call Center 112 has a good influence on public health centers, hospitals, health services, and the community. The reliability of the health service has increased because it is required to serve labor 24 hours a day. The health office also becomes more creative, active, and agile in serving the community. The Call Center 112 service is supported by better use of technology and officers than ever before, with new units and new systems, this service also provides new procedures in terms of services.

Bureaucratic reform directed at the mindset and culture set the transformation process in an effective and efficient bureaucratic order so that it can provide more optimal services to the community (Yusriadi, 2018c). The overall implementation of the 112 Call Center Innovation has run according to the expectations of the Pare-pare City Health 
Office and all Community Health Centers serving as executors and the person in charge of innovation in Call Center 112. Can see from the number of users in 2014 serving 2,277 patients, in 2015 serving 8,394 patients, in 2016 serving 13,293 patients, in 2017 serving 16,512 patients, in 2018 serving 16,795 patients using 112 Call Center patients, shows that the implementation of the 112 Call Center program has met the needs of the community in health services. Government management innovation expected to be able to provide quality public service innovations following the demands and expectations of the community (Yusriadi, 2018d).

The 112 Call Center service aims to provide information quickly on the location of communities that need health services, provide rapid treatment of health services to the community. Reduce the number of disabilities and deaths due to late treatment, provide emergency patients with assistance to health care facilities.

The Indonesian government has launched a reform of the bureaucracy that aims to develop clean, efficient, effective, and productive administration (Yusriadi, 2018b). The Call Center service unit consists of the 112 Call Center service coordinator; and technical implementers of the 112 Call Center services. The 112 Call Center service is part of the Health Service, which is open every weekday, including holidays arranged by shift. Each patient who is handled directly by medical and paramedic staff who are in charge of Call Center 112 services paid for services through claims (Community Health Insurance, Regional Health Insurance, and Social Security Organizing Agency). Through community health centers in the 112 Call Center area, the Call Center 112 service provides a stock of medicines.

Clarity of the tasks of the 112 Call Center is not to overhaul the system as a whole, organizationally the 112 Call Center is a new team, so there is no downsizing of the organizational structure in the City of Parepare. The process of a bureaucratic structure is one of the supporting factors in achieving a balance between existing resources and functions needed to make a higher performance (Yusriadi \& Farida, 2019). Call Center 112 maximizes structure functions, clarity of purpose. This health service innovation shows a clear division of tasks to avoid wasting human labor. Like the 112 Call Center, there is a fixed procedure to become an Operational Standard Procedure for executing tasks, for example, nurses and drivers get a clear division of duties and responsibilities. When obtaining a community report through a call 112 in no more than 30 minutes ambulance along with trained nurses coming directly to the house, immediately following up the patient at his home, death can suppress by the presence of trained personnel and quick response time.

One of the entry points that need intervention to improve public service delivery in Indonesia is changing the institutional framework (Yusriadi, 2018a).

Good health or well-being is a condition that is not only free from disease. Every community has the right to obtain health services, and the government is responsible for providing affordable health services to the community. The Call Center is the center of business communication activities with services provided in the form of receiving calls or calling out in large volumes (Koole \& Avishai, 2002). The innovation of public services by the Pare-pare City government through the 112 Call Center service has provided positive things to the public in health services.

The statement put forward by the minister of state apparatus shows that one of the fundamental things that need to be given particular attention from all interested parties. Is to provide a clear understanding of the entire community, especially service users about the government's seriousness in providing excellent services regarding licensing, both non-distribution and retribution through the OSS office (Umar et al., 2019).

Human resources are one of the most critical factors that cannot even be released by an organization (Yusriadi, Sahid, Amirullah, Azis, \& Rachman, 2019). Decentralization is a policy for regions to maximize the functions of a regional government authority. Proportional and optimal power in mobilizing every resource in the area will make the region have independence in developing the part (Sahabuddin, Muliaty, Farida, \& Yusriadi, 2019). 
The implementation of developmentoriented to meeting community needs requires the role of government organizations, empowerment, and innovation through community service (Awaluddin, Siraj, \& Yusriadi, 2019). The facilitative role aims to provide encouragement or uplift the target group or client so that they can create changes in their environmental conditions (Misnawati, Hasbi, Rasyid, Yusriadi, \& Zulfiqar, 2019).

\section{CONCLUSION}

In this study, to measure the implementation of public service innovations seen from three indicators: 1) concept innovation that is One form of change by the Pare-pare City government is known as the 112 Call Center. The Pare-pare City health office is in charge of general management based on Mayor Pare-pare Regulation Number 22 of 2014 concerning 112 Call Center Health Service Guidelines in the Health Office. 2) innovation typology that is providing new ways of service, there were organizational changes, procedures, and policies when this service implemented, the reliability of the health service has increased because it is required to serve labor 24 hours a day. The health office also becomes more creative, active, and agile in serving the community. The Call Center 112 service is supported by better use of technology and officers than ever before, with new units and new systems, this service also provides new procedures in terms of services.

\section{REFERENCES}

Awaluddin, A., Siraj, M. L., \& Yusriadi. (2019). The Effectiveness of The Implementation of Independent Community Empowerment Programs In Bone District. International Journal of Scientific \& Technology Research, 8(8), 352-354.

BPS. (2016). Jumlah Penduduk Kota Parepare Menurut Jenis Kelamin, 2012-2016. Retrieved from

https://pareparekota.bps.go.id/dynamictabl e/2017/11/23/24/jumlah-penduduk-kotaparepare-menurut-jenis-kelamin-20122016-.html

Koole, G., \& Avishai, M. (2002). Queueing Models of Call Centers An Introduction. Annal of Operations Research, 41-59.
Miles, M. ., Huberman, A. ., \& Saldana, J. (2014). Qualitative Data Analysis, A Methods Sourcebook (3rd ed.). USA: Sage Publications.

Misnawati, M., Hasbi, Rasyid, A. J., Yusriadi, Y., \& Zulfiqar, S. B.-T. (2019). The Role of Family Hope Program Actor in Empowering Poor Society (Case Study of Bone Regency) Indonesia. Journal of Public Administration and Governance, 9(2), 359-366.

Nasucha, C. (2004). Reformasi Administrasi Publik. Jakarta: PT. Grasindo.

Nawir, H. (2018). Cerita di Balik Lahirnya Call Centre 112 Parepare. Rakyatku.Com. Retrieved from http://rakyatku.com/tag/pemkotparepare/?url=90479/2018/03/04/ceritadi-balik-lahirnya-call-center-112-parepare

Pos, J. (2015). Call Center 112, Inovasi Wali Kota Parepare Taufan Pawe. Jawa Pos. Retrieved from

http://www2.jawapos.com/baca/artikel/17 709/call-center-112-inovasi-wali-kotaparepare-taufan-pawe\#

Sahabuddin, C., Muliaty, Farida, U., \& Yusriadi. (2019). Administration of Post-Reformation Decentralization Government. International Journal of Recent Technology and Engineering (IJRTE), 8(1), 7631-7634.

Suwarno, Y., \& Ikhsan. (2006). Standar Pelayanan Publik di Daerah. Jurnal Inovasi Pelayanan Publik, 2(1).

Tahir, M. (2018). Call Center 112 Parepare Masuk TOP 99 Inovasi Pelayanan Publik. Online 24 Always Be First. Retrieved from http://online24jam.com/2018/07/23/1134 50/call-center-112-parepare-masuk-top-99inovasi-pelayanan-publik/

Tamimi, Z. (2015). Inovasi manajemen pelayanan publik Tim Emergency Service Kabupaten Bantaeng. Politika: Jurnal Ilmu Politik, 6(1). Retrieved from https://ejournal.undip.ac.id/index.php/polit ika/article/view/9818

Umar, A., Amrin, Madani, M., Farida, U., Yusriadi, Tamsa, H., ... Misnawati. (2019). One-Stop Service Policy as A Bureaucratic Reform in Indonesia. Academy of Strategic Management Journal, 18(2), 1-12. Retrieved from https://www.abacademies.org/articles/one stop-service-policy-as-a-bureaucraticreform-in-indonesia-8027.html

Yusriadi. (2018a). Bureaucratic Reform Barriers: A Case Study on the One Stop-Integrated Service Office in Bone Regency. Jurnal Kebijakan Dan Administrasi Publik, 22(2), 146-154. Retrieved from https://jurnal.ugm.ac.id/jkap/article/view/ 34536 
Yusriadi. (2018b). Bureaucratic Reform to the improvement of public services Challenges for Indonesia. Publikauma: Jurnal Administrasi Publik Universitas Medan Area, 6. Retrieved from http://ojs.uma.ac.id/index.php/publikauma /article/view/1494

Yusriadi. (2018c). Reformasi Birokrasi Indonesia: Peluang dan Hambatan. Jurnal Administrasi Publik (Public Administration Journal), 8(2), 178-185. Retrieved from https://ojs.uma.ac.id/index.php/adminpubli $\mathrm{k} /$ article/view/1824

Yusriadi. (2018d). Tantangan Reformasi Birokrasi Berbasis E-Procurement di Indonesia. Publikauma: Jurnal Administrasi Publik Universitas Medan Area, 6(2). Retrieved from https://ojs.uma.ac.id/index.php/publikauma /article/view/1635

Yusriadi, \& Farida, U. (2019). Bureaucracy Performance in Public Services in Indonesia. Jurnal Administrare: Jurnal Pemikiran Ilmiah Dan Pendidikan Administrasi Perkantoran, 6(1), 17-24. Retrieved from https://ojs.unm.ac.id/administrare/article/v iew/9434

Yusriadi, Sahid, A., Amirullah, I., Azis, A., \& Rachman, A. A. (2019). Bureaucratic Reform to the Human Resouces: A Case Study on the One-Stop Integrated Service. The Journal of Social Sciences Research. Retrieved from https://arpgweb.com/pdf-files/jssr5(1)6166.pdf 